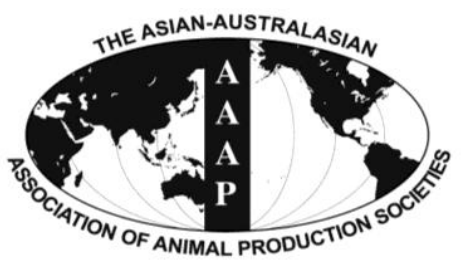

Open Access

Asian Australas. J. Anim. Sci.

Vol. 27, No. 6 : 784-790 June 2014

http://dx.doi.org/10.5713/ajas.2013.13817

www.ajas.info

pISSN 1011-2367 elSSN 1976-5517

\title{
Factor Analysis of Linear Type Traits and Their Relation with Longevity in Brazilian Holstein Cattle
}

\author{
Elisandra Lurdes Kern*, Jaime Araújo Cobuci, \\ Cláudio Napolis Costa ${ }^{1}$, and Concepta Margaret McManus Pimentel ${ }^{2,3}$ \\ Department of Animal Science, Federal University of Rio Grande do Sul, Porto Alegre, RS 91540-000, Brazil
}

\begin{abstract}
In this study we aimed to evaluate the reduction in dimensionality of 20 linear type traits and more final score in 14,943 Holstein cows in Brazil using factor analysis, and indicate their relationship with longevity and $305 \mathrm{~d}$ first lactation milk production. Low partial correlations ( -0.19 to 0.38 ), the medium to high Kaiser sampling mean (0.79) and the significance of the Bartlett sphericity test $(\mathrm{p}<0.001)$, indicated correlations between type traits and the suitability of these data for a factor analysis, after the elimination of seven traits. Two factors had autovalues greater than one. The first included width and height of posterior udder, udder texture, udder cleft, loin strength, bone quality and final score. The second included stature, top line, chest width, body depth, fore udder attachment, angularity and final score. The linear regression of the factors on several measures of longevity and $305 \mathrm{~d}$ milk production showed that selection considering only the first factor should lead to improvements in longevity and 305 milk production. (Key Words: Autovalues, Final Score, Milk Production, Linear Regression, Longevity, Holstein)
\end{abstract}

\section{INTRODUCTION}

Type traits are important when making selection and reproduction decisions in dairy cattle (Scheinder et al., 2003), influencing directly and indirectly on culling decisions (Zavadilová and Stipková, 2012), longevity and milk production (Rennó et al., 2003; Scheinder et al., 2003). They may be used as indirect predictors of longevity and milk production due to their moderate genetic correlations with these traits and can be determined early in the life of the animal (Cruickshank et al., 2002; Esteves et al., 2004).

The high number of linear type traits, as well as the high

\footnotetext{
* Corresponding Author: Elisandra Lurdes Kern. Tel: +55-5133087421, E-mail: elikern @ hotmail.com

${ }^{1}$ Embrapa Gado de Leite, Eugênio do Nascimento Street, 610, Juiz de Fora, MG 36038-330, Brazil.

${ }^{2}$ Department of Animal Science, University of Brasília, Campus Darcy Ribeiro, Brasília, DF 70910-900, Brazil.

${ }^{3}$ Institute Nacional de Ciência e Tecnologia-Informação GenéticoSanitária da Pecuária Brasileira, Belo Horizonte, MG 31270-901, Brazil.

Submitted Dec. 14, 2013; Revised Jan. 7, 2014; Accepted Feb. 24, 2014
}

degree of interrelations and colinearity between them (Montovani et al., 2005), such as those between udder and conformation traits (Campos et al., 2012), may give imprecise estimates of the relationship between these traits and longevity (Vukasinovic et al., 1997), resulting in overestimation of longevity, especially in small data banks (Visscher, 1995). According to Vukasinovic et al. (1997) a limited number of type traits, with a known biological relationship with longevity, should be used for indirect selection for the latter.

Factor analysis is a useful multivariate technique to explain the dependencies between traits (Corrales et al., 2011) as it aims to remove redundant information between correlated variables and represent them in a small group of new traits called factors (Vukasinovic et al., 1997). A large number of traits that are strongly interrelated can be analysed (Hair et al., 2009) without presenting colinearity (Corrales et al., 2011).

In this study, we aimed to evaluate the reduction in dimensionality using factor analysis of 20 linear type traits and final score to indicate those that have the strongest relationship with longevity and $305 \mathrm{~d}$ first lactation milk

Copyright @ 2014 by Asian-Australasian Journal of Animal Sciences This is an open-access article distributed under the terms of the Creative Commons Attribution Non-Commercial License (http://creativecommons.org/licenses/by-nc/3.0/), which permits unrestricted non-commercial use, distribution, and reproduction in any medium, provided the original work is properly cited. 
production in Brazilian Holsteins.

\section{MATERIAL AND METHODS}

The data used was collected by the technicians of the Service for Linear Classification, Milk Control and Genealogy of the Brazilian Association of Holstein Breeders (ABCBRH) and its state affiliates between 1996 and 2008. A total of 14,943 cows, daughters of 397 bulls, belonging to 198 herds were used.

The linear classification system used by the ABCBRH included 20 type traits as well as the final score. These traits are based on direct measurements or visual scores of morphology expressed on a scale of one to nine points. These traits were divided in seven sections as in the Canadian model: i) Conformation (ST, stature; TL, top line; WE, weight; CW, chest width; BD, body depth; LS, loin strength), ii) Rump (RA, rump angle; RW, rump width), iii) Feet and legs (FA, foot angle; BQ, bone quality; SV, side view of rear legs), iv) Anterior udder (FU, fore udder attachment; FT, fore teat placement; TL, teat length), v) Posterior udder (RH, rear udder height; RUW, rear udder width; RT, rear teat placement), vi) Mammary system (UD, udder depth; UT, udder texture; UC, udder cleft) and vii) Dairy form (AN, angularity), as well as final score (FS) where dairy form accounted for $12 \%$, conformation (18\%), feet and legs (20\%) and mammary system (8\%), rump $(10 \%)$, front udder (14\%) and rear udder (18\%) (Campos, 2012).

Longevity measures related to productive life or time in the herd were determined from production and reproduction records: total milk production in all lactations (Long 1); number of lactations initiated (Long 2); total number of days during all lactations (Long 3); time between birth and last milk control (Long 4) in months and time from first parturition to last milk control (Long 5) in months. Milk production in $305 \mathrm{~d}$ of the first lactation was also calculated.

To improve the consistency of the structure of the database and subsequent analysis, the records of cows without pedigree, dates of birth, parturition or end of lactation were removed from the data, as well as those that may still be alive, with less than two lactations, with parturition date less than 21 or greater than 48 months, without production records, cows that were not in the third month of lactation and those with a final score less than 60 points were removed from the analysis. For cows with more than one classification over the productive life, only the first was considered. Furthermore, it was considered number of classifications per technician greater than 176 , number of daughters per bull greater than nine and number of cows per herd greater than 14 .

The criterion used to verify if cows were alive included the presence of the date of the end of the last lactation, and the difference between the last parturition of the cow and the last of its herd. If this difference was less than 24 months the cow was considered to be alive. The 24 month period was used because about $95 \%$ of this population of cows showed a new calving within this period. This criterion was also used by Caetano et al. (2012) in Nelore cows.

The factor analysis included 20 linear type traits and final score using the correlation matrix between the traits to ensure that all traits are standardized in the analysis (Vucasinovick et al., 1997). The matrix of partial correlations, Kaiser statistic for sampling adequacy (MSA) using a lower limit of 0.69 , and Bartlett's sphericity test were used to determine the degree of interrelations between variables and adequacy for use in factor analysis.

Factors were chosen based on autovalues greater than one and scree test (graph) (Cattell, 1966). The point where the graph begins to become horizontal is considered indicative of the maximum number of factors to be extracted (Hair et al., 2009). Factors were rotated using varimax rotation to facilitate interpretation due to the reduction of ambiguities in non-rotated solutions (Hair et al., 2009). The value of 0.30 was used to assure a significant correlation between traits and factors.

The statistical analyses were carried out using the FACTOR procedure in SAS (Statistical Analysis System), version 9.2 (SAS, Institute, Inc., Cary, NC, USA) using the Maximum Likelihood method to reduce the dimensionality and reduce the information in a group of $\mathrm{p}$ original variables $\mathrm{Z} 1, \mathrm{Z} 2, \ldots, \mathrm{Zp}$, to a new group of variables $\mathrm{Y} 1(F 1), \mathrm{Y} 2$ $(F 2), \ldots$, Yp $(F p)$. In this analysis a few of the first factors contain the greater part of the variability contained in the original variables (Cruz and Regazzi, 1997).

The relationship of these factors with measures of longevity and $305 \mathrm{~d}$ first lactation milk production, using general linear model in the GLM procedure of SAS Statistical Analysis System, version 9.2 (SAS, Institute, Inc., Cary, NC, USA):

$$
\begin{aligned}
\mathrm{Y}_{\mathrm{ijkln}} & =\mu+\mathrm{H}_{\mathrm{i}}+\mathrm{CL}_{\mathrm{j}}+Y C_{k}+C A_{l}+b_{1}(X-\bar{X})_{n 1}+b_{2}(X-\bar{X})_{n 2} \\
& +\ldots+b_{p}(X-\bar{X})_{n p}+\varepsilon_{i j k \ln }
\end{aligned}
$$

where, $\mathrm{Y}_{\mathrm{ijkln}}$ is the longevity measure or $305 \mathrm{~d}$ milk production of the cows, in the ith fixed herd $(H)$, classified by the jth fixed classifier $(C L)$, in the kth fixed year $(Y C)$, lth fixed calving age subclass $(C A) ; \mu$ is the overall mean for the trait; $b_{p}$ are the regression coefficients estimated for the $p$ common factor scores; $(X-\bar{X})_{n p}$ are the $n$ observations of the $p$ variables; and $\varepsilon_{\mathrm{ijkln}}$ is the random error 
associated with each observation, $\varepsilon_{i j k \ln } \operatorname{NID}\left(0, \sigma_{\varepsilon}^{2}\right)$.

\section{RESULTS AND DISCUSSION}

The means of linear type scores varied between 7.28 for stature and 4.55 rear teat placement (Table 1). The traits that had an ideal score of nine points presented the greatest difference from ideal scores as defined by the ABCBRH, especially posterior udder width that had a difference of more than three points. Standard deviations are in agreement with those found in the literature for linear type traits in Holstein cattle in Brazil (Campos et al., 2012).

Linear type classification is an important tool in decision making as it focuses on the selection of animals that should have a longer herd life, expressing their productive and reproductive potential based on their morphologic traits (Pérez-Cabal et al., 2006; Posadas et al., 2008).

Angle rump, side view of rear legs, rear teat length and udder depth had Kaiser (MSA) score equal to or lower than 0.50 , a level considered unacceptable for factor analysis (Hair et al., 2009). Foot angle, fore and rear teat placement had low communality values (less than 0.05 ) and so were also excluded from the factor analysis.

Corrales et al. (2011), studying 24 linear type traits in Holstein cows, also excluded traits that were not adequate for factor analysis using principal components, deleting traits such as isquio placement, leg position - posterior vision, teat length, height of posterior placement of the teats and loin strength.

The low estimates of partial correlation, varying between -0.19 and 0.38 for linear type traits, the significant Bartlett sphericity test $(\mathrm{p}<0.001)$, general mean value of
Table 1. Ideal score, mean and standard deviation (SD) for linear type traits in Brazilian Holstein cows

\begin{tabular}{llcc}
\hline Section/trait & Abbreviation & Ideal score & Mean \pm SD \\
\hline Conformation & & & \\
Stature & ST & 7 & $7.28 \pm 1.28$ \\
Top line & TL & $5-6-7$ & $5.11 \pm 1.00$ \\
chest width & CW & 7 & $5.75 \pm 1.20$ \\
Body depth & BD & 7 & $6.20 \pm 1.07$ \\
Loin strength & LS & 9 & $6.36 \pm 1.30$ \\
Rump & & & \\
Angle & RA & $5-6-7$ & $4.99 \pm 0.99$ \\
Width & RW & 9 & $6.44 \pm 1.18$ \\
Feet and legs & & & \\
Foot angle & FA & 7 & $5.19 \pm 1.21$ \\
Bone quality & BQ & 9 & $6.59 \pm 1.34$ \\
Side view of rear legs & SV & 5 & $5.54 \pm 1.11$ \\
Anterior udder & & & \\
Attatchment & FU & 9 & $6.09 \pm 1.46$ \\
Teat placement & FT & 5 & $4.55 \pm 1.16$ \\
Teat length & UTL & 5 & $5.17 \pm 1.05$ \\
Rear udder & & & \\
Height & RH & 9 & $6.45 \pm 1.32$ \\
Width & RUW & 9 & $5.93 \pm 1.42$ \\
Teat placement & RT & $5-6$ & $6.23 \pm 1.13$ \\
Mammary system & & & \\
Depth & UD & $5-6$ & $4.89 \pm 1.16$ \\
Texture & UT & 9 & $6.82 \pm 1.13$ \\
Cleft & UC & 9 & $6.44 \pm 1.46$ \\
Dairy form & & & \\
Angularity & AN & 9 & $6.35 \pm 1.11$ \\
Final score & FS & $>80$ & $80.93 \pm 2.89$ \\
\hline
\end{tabular}

MSA score of 0.79 , with individual MSA estimates varying from 0.69 for body depth to 0.88 for top line indicated the

Table 2. Measurement of sample adequacy (MSA) and partial correlations* between linear type traits

\begin{tabular}{|c|c|c|c|c|c|c|c|c|c|c|c|c|c|c|}
\hline & ST & TL & $\mathrm{CW}$ & $\mathrm{BD}$ & LS & RW & BQ & $\mathrm{FU}$ & RH & RUW & UT & UC & AN & FS \\
\hline ST & 0.82 & & & & & & & & & & & & & \\
\hline TL & 0.05 & 0.88 & & & & & & & & & & & & \\
\hline $\mathrm{CW}$ & 0.14 & 0.11 & 0.70 & & & & & & & & & & & \\
\hline $\mathrm{BD}$ & -0.03 & 0.03 & 0.30 & 0.69 & & & & & & & & & & \\
\hline LS & 0.14 & 0.00 & -0.08 & 0.10 & 0.80 & & & & & & & & & \\
\hline RW & 0.23 & 0.02 & 0.10 & -0.06 & 0.01 & 0.82 & & & & & & & & \\
\hline BQ & -0.05 & 0.01 & -0.19 & -0.13 & 0.01 & -0.03 & 0.75 & & & & & & & \\
\hline FU & -0.01 & -0.02 & 0.04 & 0.03 & -0.05 & -0.07 & 0.00 & 0.70 & & & & & & \\
\hline RH & -0.03 & -0.05 & -0.09 & -0.05 & 0.03 & -0.05 & 0.03 & -0.03 & 0.82 & & & & & \\
\hline RUW & -0.04 & -0.01 & 0.12 & -0.01 & -0.05 & 0.18 & 0.01 & 0.02 & -0.06 & 0.85 & & & & \\
\hline UT & 0.00 & 0.01 & -0.01 & -0.10 & 0.00 & -0.03 & 0.14 & 0.03 & 0.13 & 0.13 & 0.82 & & & \\
\hline UC & -0.02 & -0.03 & 0.01 & 0.01 & -0.06 & 0.00 & -0.01 & 0.13 & 0.01 & -0.02 & 0.32 & 0.75 & & \\
\hline AN & 0.10 & 0.07 & -0.10 & 0.25 & 0.24 & 0.11 & 0.23 & -0.05 & 0.11 & 0.07 & 0.15 & -0.04 & 0.81 & \\
\hline FS & 0.12 & 0.11 & 0.10 & 0.09 & 0.07 & 0.15 & 0.08 & 0.38 & 0.26 & 0.20 & 0.12 & 0.26 & 0.18 & 0.79 \\
\hline
\end{tabular}

* Measure of sample adequacy (MSA) on the diagonal and partial correlations off diagonal; ST, stature; TL, top line; CW, chest width; BD, body depth; LS, loin strength; RW, rump width; BQ, bone quality; FU, fore udder attachment; RH, rear udder height; RUW, rear udder width; UT, udder texture; UC, udder cleft; AN, angularity; FS, final score. 
existence of significant correlations between linear type traits and the existence of true factors, reinforcing the suitability of the data for factor analysis (Table 2).

According to Hair et al. (2009), partial correlations above 0.70 may be considered high indicating the presence of high correlations between all traits but low correlations between factors which is not desirable. A similar value of general sample adequacy (0.75) was observed for linear type traits in Colombian Holstein cattle (Corrales et al., 2011).

The autovalues had estimates between -0.38 and 5.96, but only two had estimates above one, suggesting two factors with common variance for linear type traits of $76 \%$ and $23 \%$ (Table 3). The presence of negative autovalues occurs due to the restriction of the common factor analysis where the sum of the autovalues should be equal to the common variance (communality) estimated by the factors which was 7.76 and not the total variance as in the principal component analysis (SAS, 2010).

The scree test indicated the extraction of four factors (Figure 1), two more than those indicated with a critical value greater than one. A similar situation occurred with Pundir et al. (2011) studying body traits in native Indian cows. The scree test can frequently indicate a greater number of factors (two to three) compared with other tests (Hair et al., 2009). Difficulties in obtaining a clear indication of when the line in the scree test becomes horizontal as a definition the number of factors to extract also makes this test confusing (SAS, 2010).

Studies using principal components found a higher number of factors to be extracted for linear type traits. Chu et al. (2002) in China and Corrales et al. (2011) in Antioch identified four and seven factors respectively, with autovalues greater than one. Differences in the statistical

Table 3. Autovalues, common variance and accumulated proportion of factors

\begin{tabular}{lccc}
\hline Factor & Autovalue & $\begin{array}{c}\text { Common } \\
\text { proportion }(\%)\end{array}$ & $\begin{array}{c}\text { Accumulated } \\
\text { proportion }(\%)\end{array}$ \\
\hline 1 & 5.96 & 76.82 & 76.82 \\
2 & 1.80 & 23.18 & 100.00 \\
3 & 0.68 & 8.73 & 108.73 \\
4 & 0.37 & 4.71 & 113.45 \\
5 & 0.28 & 3.57 & 117.01 \\
6 & 0.15 & 1.92 & 118.94 \\
7 & 0.03 & 0.40 & 119.33 \\
8 & -0.04 & -0.46 & 118.87 \\
9 & -0.07 & -0.85 & 118.03 \\
10 & -0.14 & -1.83 & 116.2 \\
11 & -0.24 & -3.03 & 113.16 \\
12 & -0.28 & -3.66 & 109.5 \\
13 & -0.36 & -4.59 & 104.91 \\
14 & -0.38 & -4.91 & 100.00 \\
\hline
\end{tabular}

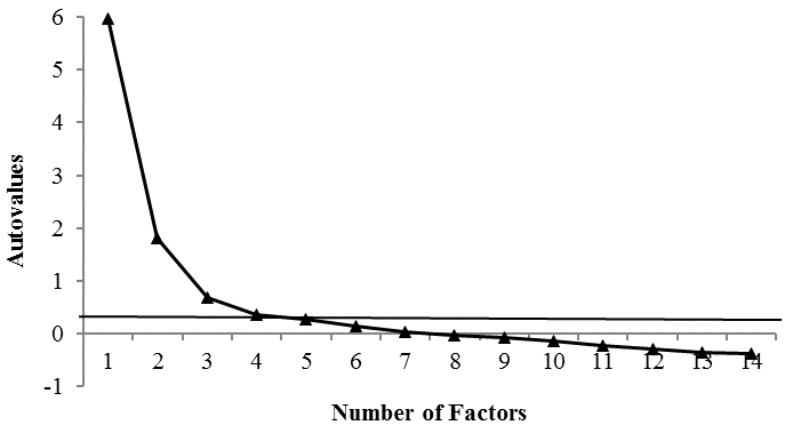

Figure 1. Relationship between number of factors and their respective autovalues from the Scree test.

methods, as well as populations, may explain the different number of extracted factors. The factor extraction method by the principal components has been the most used method in factor analysis. However, the maximum likelihood method used in this study has been highlighted by statisticians as it provides more accurate estimates in large samples, and allows testing hypotheses on the number of common factors and obtains estimates of standard errors and confidence intervals for many classes of rotated or unrotated factor loadings (SAS, 2010).

The factor weights varied from 0.00 to 0.66 for Factor 1 for body depth and final score respectively (Table 4). Most factor values were positive except for chest width and bone quality which were negative but not significant (less than 0.30 ) in Factor 1 and 2, respectively.

The correlation between the factors and original traits is represented by its weight where traits with a higher weight are more representative of that factor. Depending on the

Table 4. Estimates of factor weights for linear type traits using varimax rotation

\begin{tabular}{lccc}
\hline Trait & Factor 1 & Factor 2 & Communality \\
\hline ST & 0.16 & $0.43^{*}$ & 0.21 \\
TL & 0.10 & $0.32^{*}$ & 0.12 \\
CW & -0.19 & $0.66^{*}$ & 0.48 \\
BD & 0.00 & $0.51^{*}$ & 0.26 \\
LS & $0.30^{*}$ & 0.18 & 0.13 \\
RW & 0.21 & $0.45^{*}$ & 0.24 \\
BQ & $0.51^{*}$ & -0.17 & 0.29 \\
FU & 0.26 & $0.32^{*}$ & 0.16 \\
RH & $0.52^{*}$ & 0.04 & 0.27 \\
RUW & $0.33^{*}$ & $0.40^{*}$ & 0.26 \\
UT & $0.63^{*}$ & 0.12 & 0.41 \\
UC & $0.45^{*}$ & 0.15 & 0.22 \\
AN & $0.57^{*}$ & $0.33^{*}$ & 0.43 \\
FS & $0.66^{*}$ & $0.54^{*}$ & 0.72
\end{tabular}

ST, stature; TL, top line; $\mathrm{CW}$, chest width; BD, body depth; LS, loin strength; RW, rump width; BQ, bone quality; FU, fore udder attachment; RH, rear udder height; RUW, rear udder width; UT, udder texture; UC, udder cleft; AN, angularity; FS, final score.

* Factor weights equal to or greater than 0.30 were significant. 
Table 5. Extracted factors and their respective descriptions obtained from linear type traits in Brazilian Holstein cows

\begin{tabular}{lcl}
\hline Factor & Nome & \multicolumn{1}{c}{ Caracterization of the factor } \\
\hline 1 & Mammary & Cows with deep, wide, soft, elastic \\
& system & $\begin{array}{l}\text { udder, with Strong central ligament. } \\
\text { Strong cows with good bone quality. }\end{array}$ \\
2 & Body & $\begin{array}{l}\text { Large, deep bodied, angular cows, with } \\
\text { wide thorax and hips, good rib level and } \\
\text { sell attached udder. }\end{array}$ \\
\hline
\end{tabular}

sign and magnitude of the factor weight each factor can be interpreted physiologically or biologically (Vukasinovic et al., 1997).

Most communality estimates were low (Table 4), especially for top line, loin strength and fore udder attachment, inferring that these traits are less effective in explaining variation shared with the other traits. Final score had the highest communality (0.72), confirming its equilibrium position between linear type traits.

The higher significant factor weights in Factor 1 (Table 4) were for final score and traits related to the mammary system so this factor was called Mammary System (Table 5), but traits such as loin strength, bone quality and angularity also had a significant correlation with Factor 1.

The traits with higher weights in Factor 2 (Table 4) were related to the structure of the cow, for example stature, top line, body depth and chest width (Table 5). Factor 2 also presented significant weights for rear udder width, fore udder attachment and final score. Final score was significant in both factors, with high factor weight, communality (Table 4) and represents the full group of traits in the analysis.

Udder width and angularity also appeared in both factors but higher weights were seen in factors that did not represent the group of traits to which they belong. For example, udder width had a higher weight in Factor 2, which represented the cow structure, whereas Factor 1 represented the mammary system. The opposite was seen for angularity.

Chu et al. (2002) also found linear type traits with significant weights in different factors. According to Vukasinovic et al. (1997), difficulties occur in interpreting which traits would form factors, as a single trait may contribute to more than one factor, and sometimes with a different sign.

In general, two well defined factors were formed (Figure 2). Factor 1 had a common variance of 4.29 and Factor 2 had a common variance of 3.48 , totalling 7.76 total common variance between linear type traits.

A higher number of factors was observed by Chu et al. (2002) and Mantovani et al. (2005), which consisted of four and six factors in Holstein cows and dual purpose Rendena cows, respectively. However, in both studies, the traits related to the structure of the cow also appeared in different factors of the mammary system traits.

Including the traits of Factor 1 in selection decisions (Table 5), cows are expected to have a deep, wide udder that is soft to the touch, well irrigated with strong central ligament all important for udder health and greater production, as well as have a wide well arched back and with flat clean bones able to support the cows in high milk production as well as longevity within the herd.

When Factor 2 is used in for selection, the cows should be larger, with a wide thorax, deep body, wide hips, level top line and angular, resulting in cows with good rib arch and space between ribs, so that the cow can support its own

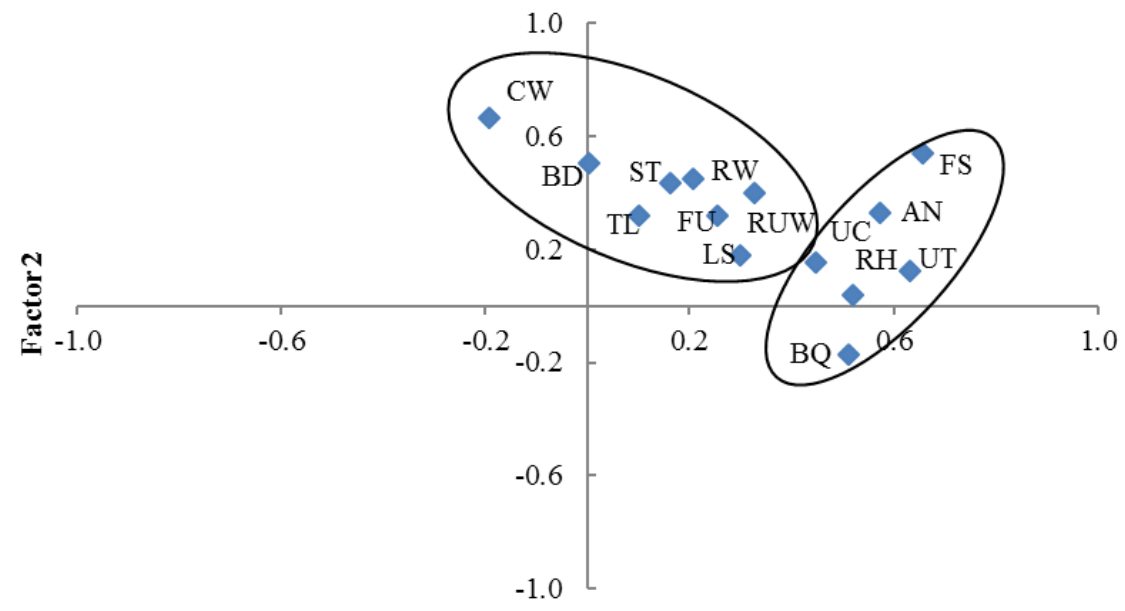

Factor 1

Figure 2. Extracted factors after varimax rotation. ST, stature; TL, top line; CW, chest width; BD, body depth; LS, loin strength; RW, rump width; BQ, bone quality; FU, fore udder attachment; RH, rear udder height; RUW, rear udder width; UT, udder texture; UC, udder cleft; AN, angularity; FS, final score. 
weight, respiratory and digestive systems. Because of the positive and significant values of these traits in Factor 2, selection for these traits should result in well inserted udders.

Factor 1 had a better relationship with longevity (Table 6). Cows with a deep, wide, elastic, soft udder with a strong central ligament and good bone structure are associated with greater time in the herd and produce more milk in the first lactation.

Involuntary culling should be avoided, such as that caused by reproduction, health and locomotion problems. A decrease in culling for these reasons increase the proportion of animals culled due to problems related to milk production, resulting in a herd with animals with greater genetic potential for production (Logrotta et al., 2010). Also, the number of adult cows in production increases and consequently the costs related to heifer rearing are offset (Rennó et al., 2003).

A relation between Factor 1 and longevity measures were significant except for with Long 4, indicating that linear type traits in Factor 1 are not related to time between birth and last milk control and at least one trait in this factor is related with the other longevity measures. Other factors such as those observed in the period from birth to first calving may be more important for Long 4 than linear type traits measured from the first lactation.

Factors that included udder and teat traits as well as body traits showed a significant relationship with Long 5, both adjusted for or not for milk production in Brown Swiss cows, indicating that cows with good udders and teats remained longer in the herd while cows with better body score contributed to lower longevity and milk production, due to the negative relationship between body traits and longevity (Vukasinovic et al., 1997).

Survival analyses also showed that udder traits such as anterior insertion, texture and depth as well as anterior teat position and udder support were more important in

Table 6. Linear regression coefficients $(b)$ of factors and their respective standard error on different longevity measures and first lactation milk production

\begin{tabular}{lcc}
\hline $\begin{array}{l}\text { Phenotypic } \\
\text { measure }\end{array}$ & \multicolumn{2}{c}{ Linear regression coefficients $(b)$} \\
\hline Long 1 & $330.041 \pm 26.930^{*}$ & $301.293 \pm 34.436^{*}$ \\
Long 2 & $0.007 \pm 0.002^{*}$ & $-0.002 \pm 0.003^{\mathrm{ns}}$ \\
Long 3 & $5.092 \pm 0.010^{*}$ & $1.714 \pm 1.290^{\mathrm{ns}}$ \\
Long 4 & $0.042 \pm 0.039^{\mathrm{ns}}$ & $-0.029+0.049^{\mathrm{ns}}$ \\
Long 5 & $0.178 \pm 0.040^{*}$ & $0.072+0.049^{\mathrm{ns}}$ \\
MP & $91.894 \pm 3.807^{*}$ & $127.965+4.838^{*}$ \\
\hline
\end{tabular}

Long 1, total milk production in all lactations; Long 2, number of lactations initiated; Long 3, total number of days during all lactations; Long 4, time between birth and last milk control in months; Long 5, time from first parturition to last milk control in months. MP, milk production in $305 \mathrm{~d}$ of the first lactation.

${ }^{\mathrm{ns}} \mathrm{p}>0.05 ; * \mathrm{p}<0.01$. determining cow longevity (Caraviello et al., 2003; Sewalem et al., 2004; Morek-Kopéc and Zarnecki, 2012).

Factor 2 only showed relationship with Long 1 and 305 $\mathrm{d}$ milk production indicating that selection based on these traits may result in an improvement in total milk production, because besides the Long1 indicate longevity, is also related to milk production, because of their training is the sum of milk yield of whole cow's life.

Estimates of genetic correlations between type traits and milk production range from -0.49 to 0.65 demonstrating that the selection for the type is performed genetic improvements can be acquired in milk production of animals (Cruickshank et al., 2002; Rennó et al., 2003).

Corrales et al. (2011) also found a significant linear relationship between $305 \mathrm{~d}$ adjusted milk production and six out of seven factors, suggesting that large cows with good udder conformation, udder depth, a strong central ligament, deep angular bodies and good quality bones tend to produce more milk.

The factor analysis reduced the number of linear type traits used in the Brazilian classification system, forming two distinct but interrelated groups, one linked to the mammary system and the other to the structure of the cow, both being related to $305 \mathrm{~d}$ first lactation milk production. The significant phenotypic between Factor 1 linear type traits and longevity measures may help in the indication of traits for use in a selection index which helps in increasing longevity, together with an increase in milk production, thereby increasing profits in Brazilian dairy systems.

Moreover, the values of the genetic correlations of longevity with udder traits and milk production, which range from -0.56 to 0.42 and -0.49 to 0.65 , respectively, may indicate the existence of genetic gains for longevity and milk production based on selection for udder traits (Cruickshank et al., 2002; Samoré et al., 2010).

In Brazil there is currently no selection index for dairy cattle which considers longevity, type traits and production traits. The formation of a selection index which ponders these traits according to their economic importance is a viable alternative (Vanraden et al., 2004) considering the moderate genetic correlation between these traits (Cruickshank et al., 2002; Zavadilová and Stipková, 2012). Several countries consider selection indices that include all of these traits to improve herd efficiency, reducing involuntary culling and increasing longevity and therefore herd profit (Vanraden, et al., 2004; Miglior et al., 2005).

Additionally it can be inferred that a possible revision of Brazilian classification system and a definition of fewer type traits, which better explain the variation in longevity and milk production are necessary. The results also indicated that the cows with good body condition tend to have higher longevity and produce more of milk. 


\section{CONCLUSION}

The factor analysis as useful in reducing the dimensionality of the group of linear type traits studied, forming two factors and eliminating seven redundant traits.

Selection for Factor 1, which included the traits loin strength, bone quality, rear udder width, udder texture, udder cleft and final score, showed a positive association with longevity and $305 \mathrm{~d}$ milk in first lactation, indicating that this factor could contribute to the improvement of these two characteristics in dairy cows in Brazil.

\section{ACKNOWLEDGMENTS}

Thanks are due to the Brazilian Holstein Breeders Association (ABCBRH) for the data, the Coordenação de Aperfeiçoamento de Pessoal de Nível Superior (CAPES) and $\mathrm{CNPq}$ for scholarships as well as INCT- Pecuária (CNPq/MCT/FAPEMIG) for financing.

\section{REFERENCES}

Caetano, S. L., G. J. M. Rosa, R. P. Savegnago, S. B. Ramos, L. A F. Bezerra, R. B. Lôbo, C. C. P. De Paz, and D. P. Munari. 2012. Characterization of the variable cow's age at last calving as a measurement of longevity by using the Kaplan-Meier estimator and the Cox model. Animal 7:540-546.

Campos, R. V. 2012. Genetic Parameters for Linear Type and Yield Traits in Holstein Cows in Brazil. Ph.D. Thesis, Federal University of Rio Grande do Sul, Porto Alegre.

Campos, R. V., J. A. Cobuci, C. N. Costa, and J. B. Neto. 2012. Genetic parameters for type traits in Holstein cows in Brazil. R. Bras. Zootec. 41:2150-2161.

Caraviello, D. Z., K. A. Weigel, and D. Gianola. 2003. Analysis of the relationship between type traits, inbreeding, and functional survival in Jersey Cattle using a Weibull Proportional Hazards Model. J. Dairy Sci. 86:2984-2989.

Cattell, R. B. 1966. The scree test for the number of factors. Multivariate Behav. Res. 1: 245-276.

Chu, M. X. and S. K. Shi. 2002. Phenotypic factor analysis for linear type traits in Beijing Holstein cows. Asian Australas. J. Anim. Sci. 15:1527-1530.

Corrales, J. A., M. Cerón-Muñoz, J. A. Cañas, C. R. Herrera, and S. C. Calvo. 2011. Relationship between type traits and milk production in Holstein cows from Antioquia, Colombia. Rev. MVZ Córdoba 16:2507-2513.

Cruickshank, J., K. A. Weigel, M. R. Dentine, and B. W. Kirkpatrick. 2002. Indirect prediction of herd life in guernsey dairy cattle. J. Dairy Sci. 85:1307-1313.

Cruz, C. D. and A. J. Regazzi. 1997. Biometric Models Applied to Genetic Improvement. 2nd. ed. Viçosa, Federal University of Viçosa, p. 390.

Esteves, A. M., J. A. G. Bergmann, M. C. Durães, C. N. Costa, and H. M. Silva. 2004. Genetic and phenotypic correlations between type traits and milk production in Holstein cattle. Arq. Bras. Med. Vet. Zootec. 56:529-535.
Hair, J. R. J. F. 2009. Multivariate data analysis. 6th ed. Bookman, Porto Alegre, p. 679.

Lagrotta, M. R., R. F. Euclydes, R. S. Verneque, M. L. Santana Júnior, R. J. Pereira, and R. A. Torres. 2010. Relationship between morphological traits and milk yield in Gir breed cows. Pesq. Agropec. Bras. 45:423-429.

Mantovani, R., I. Cerchiaro, and B. Contiero. 2005. Factor analysis for genetic evaluation of linear type traits in dual purpose breeds. Ital. J. Anim. Sci. 4:31-33.

Miglior, F., B. L. Muir, and J. Van Doormaal. 2005. Selection Indices in Holstein cattle of various countries. J. Dairy Sci. 88: 1255-1263.

Morek-Kopéc, M. and A. Zarnecki. 2012. Relationship between conformation traits and longevity in Polish Holstein Friesian cattle. Livest. Sci. 149:53-61.

Pérez-Cabal, M. A., C. García, O. Gonzàlez-Recio, and R. Alenda. 2006. Genetic and phenotypic relationships among locomotion type traits, profit, production, longevity, and fertility in Spanish dairy cows. J. Dairy Sci. 89:1776-1783.

Posadas, M. V., H. H. M. Valdenegro, and F. J. R. López, 2008. Genetic parameters for conformation traits, stayability and milk yield for Holstein dairy cattle in Mexico. Téc. Pecu. Méx. 46:235-248.

Pundir, R. K., P. K. Singh, K. P. Singh, and P. S. Dangi. 2011. Factor analysis of biometric traits of Kankrej cows to explain body conformation. Asian Australas. J. Anim. Sci. 24:449-456.

Rennó, F. P., C. V. Araújo, J. C. Pereira, M. S. Freitas, R. A. Torres, L. N. Rennó, J. A. G. Azevêdo, and F. R. Kaiser. 2003. Genetic and phenotypic correlations among type traits and milk yield of Brown Swiss cattle in Brazil. R. Bras. Zootec. 32:14191430.

SAS Institute Inc. 2010. SAS/STAT User's Guide: ver. 9.22. SAS Institute Inc., Cary, NC, USA.

Samoré, A. B., R. Rizzi, A. Rossoni, and A. Bagnato. 2010. Genetic parameters for functional longevity, type traits, somatic cell scores, milk flow and production in the Italian Brown Swiss. Ital. J. Anim. Sci. 9:145-152.

Sewalem, A., G. J. Kistemaker, F. Miglior, and B. J. Van Doormaal. 2004. Analysis of the relationship between type traits and functional survival in Canadian Holsteins using a Weibull Proportional Hazards Model. J. Dairy Sci. 87:3938-3946.

Schneider, M. P., J. W. Durr, R. I. Cue, and H. G. Monardes. 2003. Impact of type traits on functional herd life of Quebec Holsteins assessed by survival analysis. J. Dairy Sci. 86:40834089.

Vanraden, P. M. 2004. Invited review: Selection on net merit to improve lifetime profit. J. Dairy Sci. 87:3125-3131.

Visscher, P. M. 1995. Bias in multiple genetic correlation from halfsib design. Genet. Sel. Evol. 27:335-345.

Vukasinovic, N., J. Moll, and N. Kunzi. 1997. Factor analysis for evaluating relationships between herd life and type traits in Swiss Brown cattle. Livest. Prod. Sci. 49: 227-234.

Zavadilová, L. and M. Śtípková. 2012. Genetic correlations between longevity and conformation traits in the Czech Holstein population. Czech J. Anim. Sci. 57:125-136. 